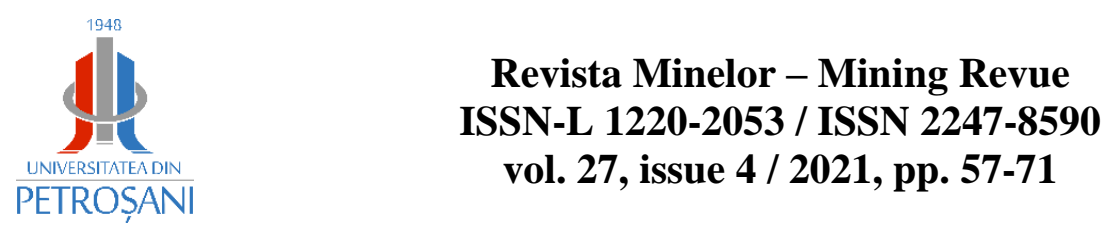

\title{
CONSIDERATIONS REGARDING THE CLOSURE OF THE MINES IN VALEA JIULUI
}

\author{
Liliana ROMAN ${ }^{*}$ \\ ${ }^{1}$ University of Petroșani, Petroșani, Romania e-mail lilianaaprilie40@yahoo.com
}

DOI: $10.2478 / \operatorname{minrv-2021-0035~}$

Keywords: mining, closure, Valea Jiului

Abstract: The paper, starting from a series of general considerations regarding the closure of a mine, makes an analysis, according to the available data, of the manner some of the mines in the Valea Jiului were closed. It is specified that the relatively short time since the closure of the first mine in the Valea Jiului (30 years) did not allow to highlight any mistakes / errors of closure, which would have significant repercussions on the surface land and, in general, on the environment. However, more or less serious problems have already been reported, which arose after the closure of some mines, problems that appear in the last part of this paper.

\section{Introduction}

Romania has undergone an extensive industrial restructuring in the last 30 years, including the decrease of domestic production and the operational closure of most mines, which led to job losses, generated economicsocial and environmental effects that severely affected the quality. the lives of the inhabitants of the communities in the mining areas.

The paper refers to the situation of mining in Valea Jiului in the context of closing some mining perimeters in this area.

In 1989, there were 15 mining operations in Valea Jiului, which annually exploited 11 million tons of coal with a volume of 1,500,000 m3 of tailings, and underground mining works (wells, galleries, inclined planes, suites, preparation works, investment works, aeration and felling works), totaled thousands of kilometers. The staff employed in the 15 farms was about 55,000 people [3].

Today, within the Hunedoara Energy Complex, there are still 2 mining operations (Livezeni and Vulcan) with a production of approx. 450,000 t/year. The mines closed as follows: Iscroni mine - 1990, Lonea Pilier mine - 1994, Câmpu lui Neag mine - 1999, Petrila Sud mine - 1999, Dâlja mine - 2001, Valea de Brazi mine 2004, Aninoasa mine - 2006, Bărbăteni mine - 2007, Petrila mine-2015, Paroșeni and Uricani mines- 2017, Lonea and Lupeni mines (in the process of closing) - 2022, and the employed staff is approx. 4000 people. To these is added the closure of quarries and micro-quarries (Câmpu lui Neag, Jieț a.o.) [2].

The paper, based on a series of general considerations regarding the closure of a mine, presents the criteria on the basis of which the decision to close the mines in the Valea Jiului was made and according to the procedures for closing the mines makes an analysis, as far as available, they closed some of the mines in Valea Jiului.

The methods and technologies for closing a mine are also presented.

It should be noted that the relatively short time since the closure of the first mine in Valea Jiului (30 years) did not allow to highlight any errors / errors of closure, which would have significant repercussions on land and in general on the environment.

However, more or less serious problems have already been reported, which arose after the closure of some mines, problems that I will present in the last chapter of this paper.

\footnotetext{
* Corresponding author: Roman Liliana, Ph. D. student. eng. University of Petroșani, Petroșani, Romania (University of Petroșani str. Universitatii no.20, 332006 Petroșani, e-mail: lilianaaprilie40@yahoo.com)
} 


\section{General considerations on mine closure}

\subsection{Legal and institutional framework for mine closure}

By Government Ordinance no. 11 of January 24, 2000, the Loan Agreement between Romania and the International Bank for Reconstruction and Development on the financing of the Mine Closure and Social Impact Mitigation Project, amounting to $\$ 44.5$ million, was ratified. The project was constituted by a first support, granted by the World Bank, for the restructuring of the mining sector in Romania and was developed as a pilot project, aiming at improving the institutions and completing the necessary procedural regulations to address them, in an extended framework of the problems of restructuring the mining sector, in correlation with the diminishing social impact resulting from the restructuring.

The implementation of the agreement was carried out by the Project Management Union (PMU), established within the Ministry of Economy and the Project Implementation Unit (PIU), set up at the level of entities, with responsibilities in carrying out the loan [9]. The Project Management Unit proposed and promoted over 70 legislative acts, specific to extractive activities, mine closure and social protection.

The main directions of action of the PMU, for the mine closure component, are [10]:

- Ensuring the legal framework for project management and implementation;

- The institutional framework for carrying out the activity of closing and greening the mines.

For the coordination of the operative activities, S.C. CONVERSMIN S.A. was established. It acts for and on behalf of the Ministry of Economy in the sense of managing the annual funds allocated from the state budget, for contracting the execution of mine closure works.

Starting with the year 2000, some mines were preserved and then closed permanently. This category included some objectives for which the expenses exceeded more than the revenues and for the maintenance of which it was necessary to allocate important public funds, but also those for which the geological reserves or geological research works were exhausted no longer justifies the continuation of the activity.

\subsection{Criteria underlying the closure of the mines}

In the following, three criteria will be briefly presented, which were the basis for the decision to close the mines in the Valea Jiului without detailing them, because they are not the express object of this article.

The decision to close a mining objective will be required following a complex analysis of the factors that influence its efficiency and which can be grouped into: natural and constructive factors; economic factors; socio-political factors.

Following such analyzes, several categories of units can be established: profitable (class I); attractive to the requirements of the reform (class II); with an average degree of attractiveness (class III); with a low degree of attractiveness (class IV) and unattractive units (class V) [1,4,7,9].

\subsubsection{The economic criterion}

This complex criterion takes into account: the need for useful minerals, selling prices, the level of costs for obtaining minerals, the volume of equipment needed for refurbishment, the costs of closing mines, the costs of measures to ensure social protection of workers removed from the process of production. In order to solve the problem, there is a need to carry out a complex study, being completed several stages [4].

Under market economy conditions, the ratio $I$ between the unit cost of production of $C P$ and the selling or selling price of $C V$ will be taken into account. If $I \leq 1$ mines are profitable (class I), for I $>1$ (classes II$\mathrm{V})$ the mines are unprofitable, the degree of unprofitable, increasing as the class increases.

\subsubsection{The integrative criterion}

For a more realistic assessment of each operation, criterion [4] proposes the comparative analysis of a set of technical and economic indicators, namely: extracted physical production, average number of staff, physical labor productivity, open reserve, prepared reserve, exploitable reserve, the degree of mechanization, the unit cost and the expenses per 1000 lei production of goods to which a score is awarded, so that by summing up the points obtained a hierarchy of mining units can be made according to which a correct decision can be made regarding the mine will enter the conservation/closure process. 


\subsubsection{The criterion of points}

The method has the advantage of sufficient flexibility, as well as the speed with which the ranking of companies is determined, from a financial point of view [4].

The technical-economic indicators taken into account are: recalculated extracted production, extracted physical production, total gross loss, unit cost of production, total expenses per 1000 lei of goods production, material expenses per 1000 lei of goods production, physical labor productivity, price of settlement.

It is considered that mining units whose total scores exceed 100 are viable, and those below this threshold will fall into the category of non-viable. And in this case, the entry into the conservation/closure process will be done gradually, starting with the mining unit, which holds the last place in the hierarchy.

\subsection{Procedures for closing a mine}

When closing a mine, the following four stages/phases must be completed [1]:

$>$ Stage/phase I includes:

- the initiative to cease operating;

- elaboration of the Activity Cessation Plan (PIA), obtaining the fundamental approvals and submitting for approval; - the taking over by the Central Mining Authority (through the Mine Closures Directorate-D.Î.M.) from the licensee of the objectives in order to capitalize on them.

$>$ Stage/phase II includes:

- elaboration of the Technical Closing Project (PT), of the specifications and of the tender documentation, obtaining the approvals and submitting for approval.

$>$ Stage/phase III includes:

- implementation of the Technical Closing Project;

- monitoring the closure of the operation and the reception of the works;

- handing over the available land to the forestry or agricultural directorate.

$>$ Stage/phase IV includes:

- monitoring the objectives that maintain their functionality after the closure of the operation as well as their maintenance and operation.

The Activity Cessation Plan (PIA) is the one that provides the details of the actions necessary for the effective implementation of the mine closure measures. It must include the following activities [10]: motivation for cessation of activity; the technical program for decommissioning or conservation of the operation, which will also include the program for monitoring the post-closure environmental factors; the social protection program for staff through redeployment and / or professional retraining, financial compensation and / or regional development measures, for the creation of new jobs; the water management permit and the environmental permit, for closure; decommissioning and land clearance procedure.

The Technical Closing Project (PT) for mine closure and environmental restoration is a detailed plan, which evaluates the actions and measures provided by the mine closure procedures, both from a technical point of view, including the necessary works, physical closure of the mine and restoration of the affected environment, with reference to information on the mine subject to closure and shall be approved by order of the relevant ministry. It will be accompanied by the social protection plan, in consultation with the Community consortium.

\subsection{Methods and technologies for closing a mine}

The closure of a mine will be based on a technical project that will include [1]:

$>$ Technical solutions for closing the mining works related to the surface;

$>$ The way of closing the mouth of the mining works related to the surface;

$>$ Technical solutions for closing underground mining works;

$>$ Technical solutions for closing the abattoirs;

> Carrying out the general and partial ventilation during the closing period;

$>$ Recovery of the technical-productive infrastructure of the mines in liquidation;

$>$ Valorization or demolition of constructions and other surface objectives;

> Post-closure monitoring of underground and surface insulation mining constructions;

$>$ Greening of land areas affected by mining. 


\section{Closure of the mines in the Valea Jiului}

\subsection{Evaluation of the mines in Valea Jiului according to the closure criteria}

Valea Jiului is the only mining basin in Romania where a coal mine is currently exploited, which has important balance reserves, which can ensure the requirements of the beneficiaries (CET Paroșeni and MintiaDeva), for a period of several decades. The mines from Valea Jiului (fig.1), with a traditional activity in coal extraction, have the most qualified personnel and an adequate infrastructure, both for the actual extraction and for the transport to the beneficiaries.

At the same time, however, the complicated tectonics of the deposit makes this deposit one of the most complex coal deposits in the world and very difficult to exploit through the methods and technologies widely used worldwide. Therefore, the mining activities in the mining basin of Valea Jiului are at an impasse from which it could emerge, not only through technical-organizational measures but also through responsible political decisions.

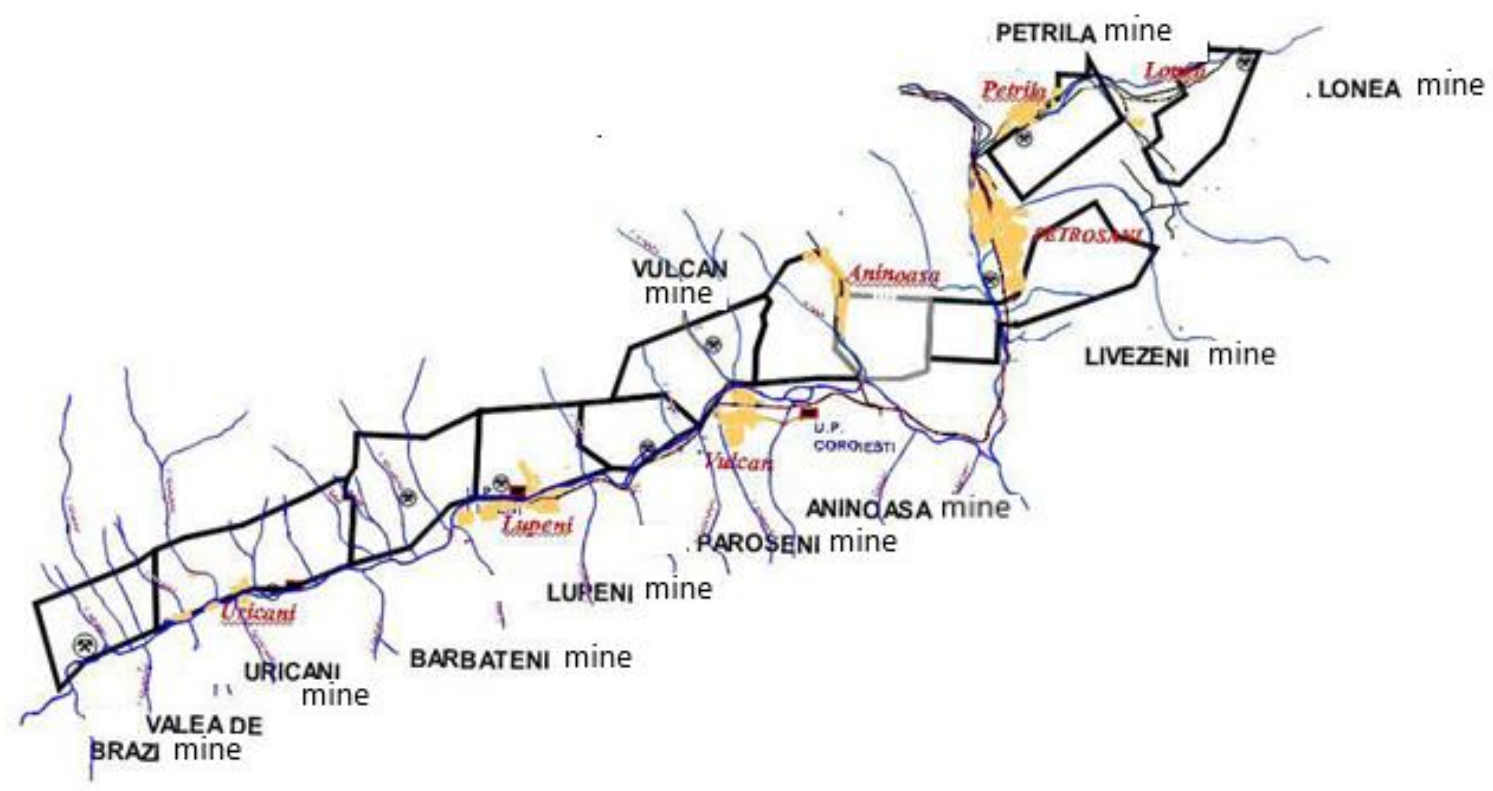

Figure 1. Mining perimeters in Valea Jiului mining basin [11]

After 1989, when the created situation imposed the support of the mining sector by the state with a great budgetary effort, the non-stop decline of mining in Valea Jiului begins.

There are several key benchmarks in its decline, caused in particular by the so-called restructuring programs (especially those from 1997 to 2000): mass redundancies; high compensatory payments for redundant staff; dramatic increase in production costs; the drastic decrease of investments by approx. 20 times the value of those before 1989. All this led to a decrease in the production extracted (by 41\%), the number of employees (by 60\%), the fluctuation of production costs and, in particular, the total neglect of refurbishment and modernization of all technological processes in the underground and on the surface of a mine.

Thus, after a century of efficiency and half a century of investments materialized in an extensive development, which led to the formation of a first-class mining basin, we are witnessing today, after three decades, a sad end of a mining characterized by inefficiency, rapidly declining production, risks and uncertainties for those still working underground.

After 1990, it is difficult to talk about investments in the mining of Valea Jiului in the absence of a future energy strategy, indiscipline in work and management of the Coal Company, to which are added more general causes such as the strategy to reduce emissions. carbon dioxide, lower economic efficiency of coal based energy, the development of unconventional energy sources less polluting and why not and the detonation of the social bomb represented by the nearly 60,000 employees concentrated in a relatively small area such as Valea Jiului.

A first ranking of the 10 mines in Valea Jiului remaining in operation in 2001, based on scientific criteria, was made in 2002 applying the technical-economic indicators achieved at the end of 2001. 
Table 1 summarizes the hierarchy of the 10 mining operations in Valea Jiului, which were operating at that time, ranking obtained according to the three criteria presented in $\$ 2.2$.

Table 1. Hierarchy of mines in Valea Jiului according to evaluation criteria

\begin{tabular}{|c|l|c|c|c|}
\hline \multirow{2}{*}{ No. crt. } & \multirow{2}{*}{ Mine } & \multicolumn{3}{|c|}{ Criteria for evaluating the conservation-closure } \\
\cline { 3 - 5 } & & Economic Class & Integrator Score & Points Score \\
\hline 1 & Valea de Brazi & V & 54 & 108.3 \\
\hline 2 & Uricani & III & 89 & 120.4 \\
\hline 3 & Bărbăteni & IV & 54 & 89.7 \\
\hline 4 & Lupeni & IV & 85 & 116.2 \\
\hline 5 & Paroșeni & IV & 64 & 95.5 \\
\hline 6 & Vulcan & IV & 73 & 103.4 \\
\hline 7 & Aninoasa & V & 45 & 56.9 \\
\hline 8 & Livezeni & IV & 82 & 101.0 \\
\hline 9 & Petrila & IV & 66 & 104.9 \\
\hline 10 & Lonea & III & 74 & 103.7 \\
\hline
\end{tabular}

It should be noted that the ranking of these mines was based on the detailed technical and economic indicators presented in works $[1,4]$.

Analysing table 1 we find the following:

- According to the economic criterion, it appears that no mining unit in the Valea Jiului was, at that time, in classes I and II, most belonging to classes III (2), IV (6) and V (2), i.e. units with grade medium of attractiveness, low degree of attractiveness and respectively unattractive.

- According to the integrative criterion, considering the viability threshold of 58 points, corresponding to average values of the indicators evaluated, three mines Valea de Brazi, Bărbăteni and Aninoasa were below this threshold, being considered non-viable.

- According to the points criterion, three mines, Bărbăteni, Paroșeni and Aninoasa were located below the threshold of 100.

Following these assessments, the decision was made to declare the Valea de Brazi, Bărbăteni and Aninoasa mines unviable and to enter the closure process. At the time of the cessation of state subsidies, in 2011, 7 mines were in operation in Valea Jiului: Lonea, Petrila, Livezeni, Vulcan, Paroșeni, Lupeni and Uricani.

Also now, a new evaluation will be made at the level of CNH-SA Petroșani from a technical, economic and social point of view to decide which of the seven mines will survive economically without social assistance.

Following such an analysis, two categories of units were established: non-viable (which must enter the closure process) and viable (those that will continue their activity). The analysis was based on the projection of the following technical and economic indicators for the period 2011-2018.

The scores obtained by the seven mining operations, analysed and then in operation are shown in table 2 [5].

Table 2. Scores obtained from mines

\begin{tabular}{|c|l|c|c|c|}
\hline No. crt. & \multicolumn{1}{|c|}{ Mine } & Technical score & Economic score & TOTAL \\
\hline 1 & Lonea & 50.6 & 46.6 & 99.2 \\
\hline 2 & Petrila & 16.5 & 17.3 & 33.8 \\
\hline 3 & Livezeni & 55.0 & 53.8 & 108.8 \\
\hline 4 & Vulcan & 41.6 & 58.9 & 100.5 \\
\hline 5 & Paroșeni & 20.8 & 40.7 & 61.5 \\
\hline 6 & Lupeni & 49.1 & 49.8 & 98.9 \\
\hline 7 & Uricani & 21.4 & 22.8 & 44.2 \\
\hline
\end{tabular}

It is observed that the Petrila, Paroșeni and Uricani mines (marked in red), obtained the lowest scores and were declared unviable, entering the closing process (2011-2017).

In 2012, the Valea Jiului National Mine Closure Company (SNIMVJ) was established, which took over all the mines in different stages of cessation of activities (conservation closure). 
Between 2011 and 2015 there were four viable mines in Valea Jiului: Lonea, Livezeni, Vulcan and Lupeni. The analysis of viable mines stopped until the end of 2015, when based on Feasibility Studies, developed by the University of Petroșani (for the Lonea mine) and S.C. Universal Cerc Project SRL (for the Livezeni, Vulcan and Lupeni mines), solutions were presented to continue the activities at these mines, with the acceptance of appropriate investments.

Following these studies, but also due to their uncertain state from 2016-2017, as CEH- Hunedoara (CEHSA Petroșani) enters or leaves insolvency, the Romanian Government adopted (November 2016) a memorandum on increasing aid state granted to the National Society of Mine Closures Valea Jiului (SNIMVJ), with 129.129 million lei (approx. 28.7 million euros), for the inclusion in the closure program (until the end of 2018), of two mines, which were considered non-viable: Lonea and Lupeni [3].

So, at present, there are only two viable mines in Valea Jiului: Livezeni and Vulcan.

\subsection{Brief presentation of the mines closed or in the process of closing}

In the following, based on the Activity Cessation Plans (PIA) and Technical Closing Projects (PT) available, there will be a brief presentation of how it was done or the closure of seven of the 13 mines that have been ceased activity after $1990[12,14]$.

\subsubsection{Uricani mine}

The motivation for closing the mine was that the activity of exploiting the deposit within it becomes economically unprofitable and the confirmation of reserves is uncertain.

The coal deposit from the Uricani perimeter is located at relatively large depths (over $400 \mathrm{~m}$ ), located in complex geological and tectonic conditions, which make it difficult to track and exploit useful seams, adding to them the tendency to self-ignite coal and the possibility of forming atmospheres. potentially explosive consisting of mixtures of flammable ground gases and air.

In this perimeter, the object of exploitation was seams 3-5, 8-9 and 14-17.

The activity of coal extraction from the underground of the Uricani mine stopped in 2017, after which the exploitation entered the established greening and closure program, according to the notifications sent to the European Commission. In 2018-2019, the recovery and removal of equipment that is underground and can be recovered continued. In the following years, 2019-2020, the coal deposit was secured, the waters in the galleries were drained, the main fan station was stopped and the wells were closed and the underground connections to the surface were closed. Greening of surface land began in 2020.

Starting from the requirements of the integral and efficient use of the territory and taking into account the fundamental principles of ecological rehabilitation, the specialists together with the representatives of the local community, decided to restore the lands mainly in the agricultural circuit.

The return to the economic circuit of the lands degraded by the mine activity requires the redevelopment and modeling of the surfaces and then their recultivation.

The Uricani mine carried out its activity in several premises: the main enclosure, the explosive depot, the tailings dump, the east aerial well enclosure, the western aeration well enclosure, the Sterminos enclosure and the capture from the Sterminos well and the Valea de Brazi enclosure. not recoverable).

The decommissioning-demolition of all the objects within these enclosures was carried out according to a methodology presented schematically in figure 2 , and in figure 3 are presented some constructions in different phases of deactivation-demolition.

As the remediation and intervention works provided at the mining premises are completed, the land related to them will be subjected to modeling and geometrization works to ensure their integration into the local landscape and the optimal drainage of water from precipitation.

The closure of the underground mining works at the Uricani mine was carried out in stages, respecting the principle that they be made in retreat from the limits of the development-exploitation field, to the main aeration circuits under the general depression of the mine, including to the surface connections.

The method used to close the exploited spaces, in order to prevent and combat mine fires, was the siltation (the necessary ash / water ratio is made at the siltation station and can vary from 1:1 to 1:12, depending on a series of technological factors).

Due to the relatively large depth of exploitation as well as the surface morphology of the land (mountainous area), in the case of the Uricani mine, the manifestation of the mining subsidence phenomenon has not been found so far. 


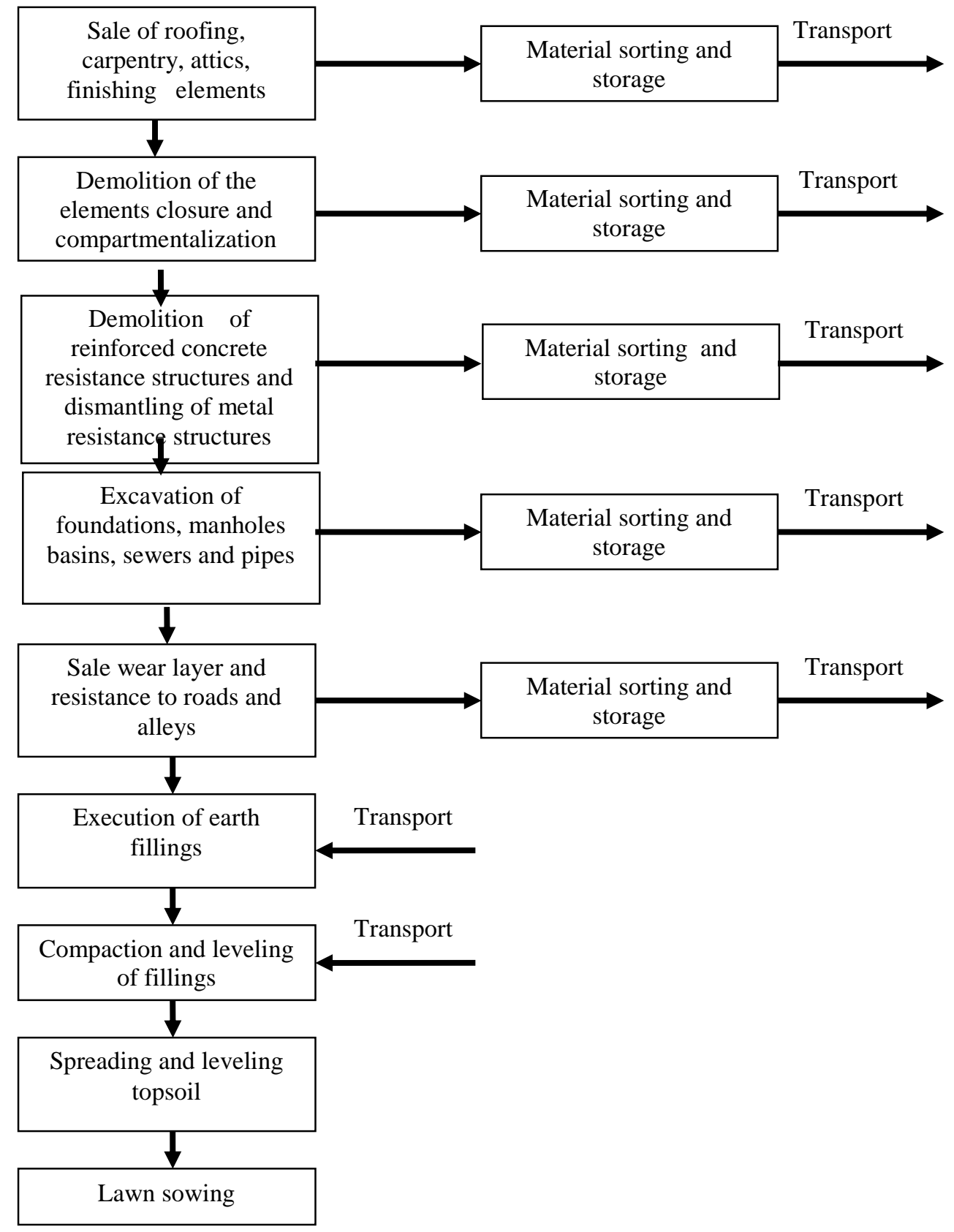

Figure 2. Logic scheme for demolition and site rehabilitation [12]
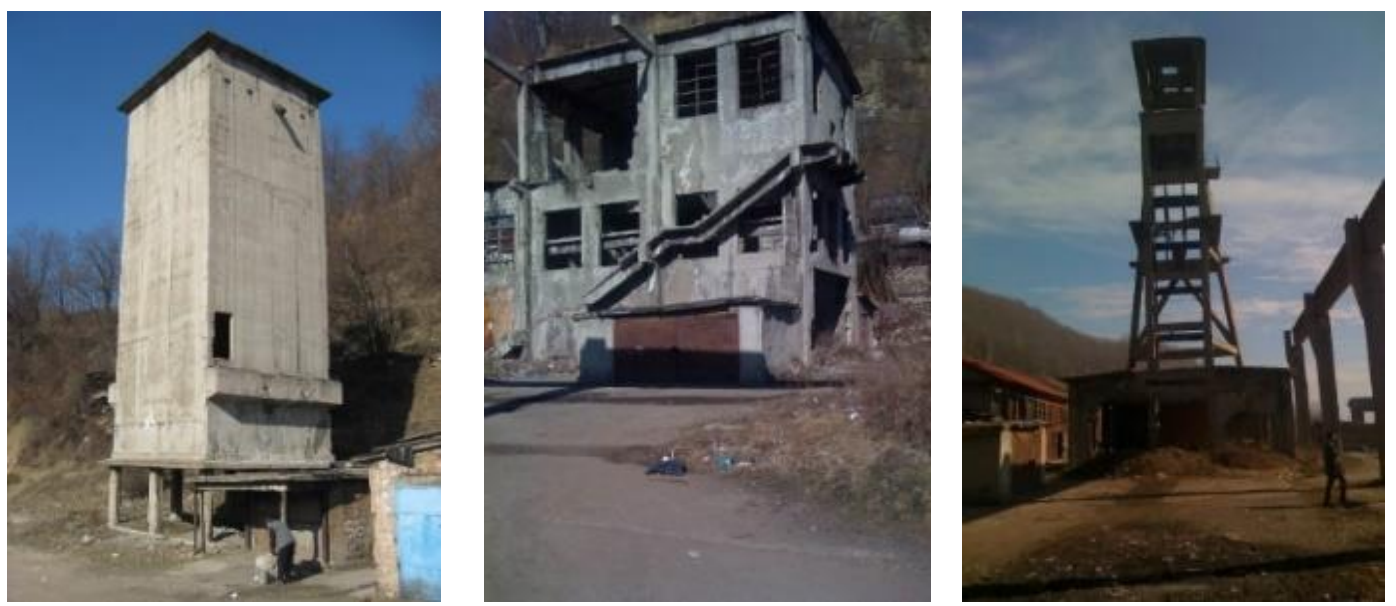

Figure 3. Some constructions from mine yard that is being demolished [12] 
However, the mining activity carried out within the Uricani mining perimeter caused a series of negative effects on the land area related to it, such as:

- the modification of the relief during the construction of the enclosure and the systematic influence of the flora and fauna of the area;

- reduction of agricultural and forestry areas, by occupying them with the objects of mining;

- modification of natural hydrogeological conditions due to the needs of underground exploitation;

- changes to the infrastructure from a technical and social point of view;

- environmental pollution, both through coal mining and related processing industries

\subsubsection{Lupeni mine [8]}

It is the perimeter with the largest mining operation in the basin. The deposit, due to the morphology of the foundation formations, is higher than in the adjacent areas. In general, the syncline structure with the more developed northern flank is maintained. Due to a fault system (generally oriented north-south), the deposit is compartmentalized into tectonic blocks. In the Lupeni mining perimeter are found all the layers 3-18, economic importance presenting the seams 3,4,5,8,9,13,14,15 (which are the object of exploitation).

Lupeni mine is one of the oldest mining operations in Valea Jiului mining basin, with an extensive mining structure on several levels of exploitation (horizons), with several enclosures, which have lost their usefulness as the depth increases. coal mining.

The mine is currently in the process of closing/preserving.

The underground exploitation of the coal seams from the Lupeni mining field had and still has major implications in terms of the stability of the land, but also of the surface constructions. Most of the affected buildings (residential houses) are on one level, made of brick walls, on monolithic concrete or river stone foundations and are over 50 years old.

Due to the differentiated displacements of the surface, generated by the underground exploitation, the movement propagated through the foundation of the buildings, to their superstructure, initially causing traction and shear cracks, which gradually progressed over time until the structural elements are completely decomposed.

Starting with 2008, in the perimeter of block V, from the Lupeni mine, three pits appeared successively on the surface of the current land, in the areas of influence of panels P6/I, P9, P7 and P10, atypical for the geomining conditions in Valea Jiului [9]

\subsubsection{Paroşeni mine [12]}

The Paroșeni mine has been operating for 51 years. The opening and preparation works began in 1963, but the operation of the first coal wagon was completed on October 7, 1966.

The perimeter of the mine is between the perimeters of Lupeni, to the west, and Vulcan, to the east, in an area where the deposits of horizon 3 are heavily eroded. The deposit is strongly tectonized, an important transverse fault, located on Valea Lupului, separating the western domain of the basin from the eastern one. In the perimeter were found all the known layers of the basin, economic importance presenting the seams 3, 5, 8, $9,13,14,15,18$. Qualitatively, the coal mined in the perimeter is an energetic one.

The Paroșeni mine was closed at the end of 2017, after more than half a century of operation, during which time, 27 million tons of coal were extracted from its depths. Starting with January 1, 2020, the surface demolition and closure of underground spaces began, the operation entering the process of closure and greening. This means that all underground activities will be completed, all underground access roads will be closed and all surface buildings will be demolished.

Figure 4 shows some constructions that are being demolished from the Paroșeni mine.

All surface constructions that lose their utility once the mine is closed have been provided for decommissioning and demolition, and the land released from the constructions will be returned to the economic circuit (table 3).

In order to protect the deposit, isolation works were carried out on the mining access works to the abatements, which were dammed with insulation dams to prevent endogenous fires.

The operations of closing the underground mining works were carried out in the period $2011 \div 2018$, annually, in eight stages, considering the production staggering until 2017 inclusive. 


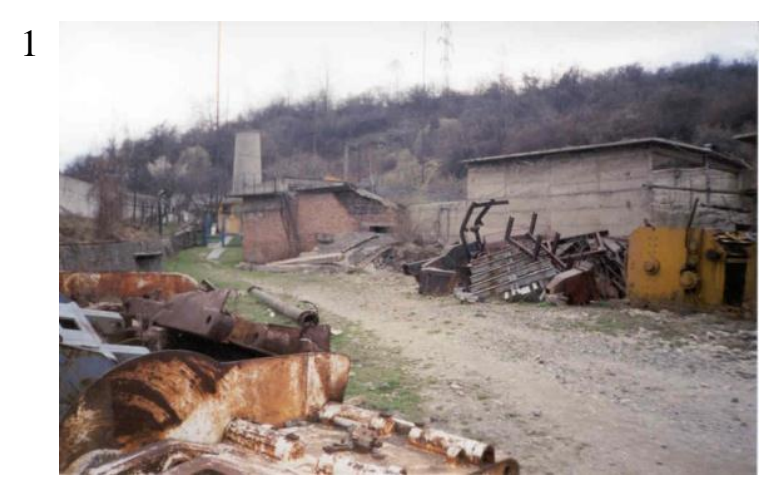

3

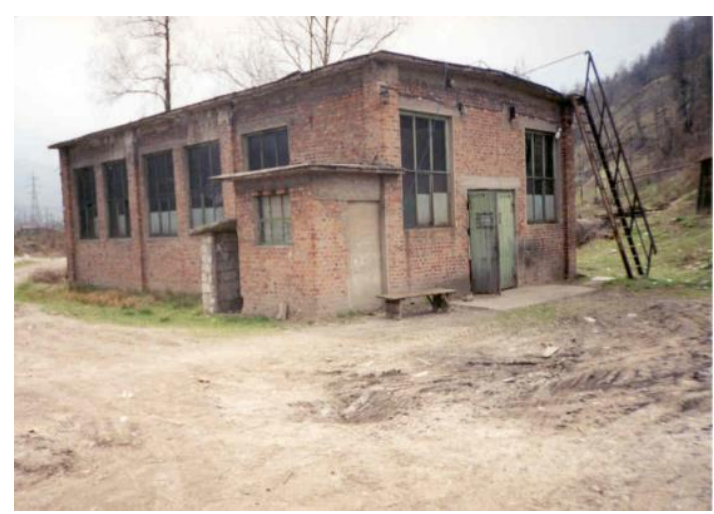

pp. $57-71$

2

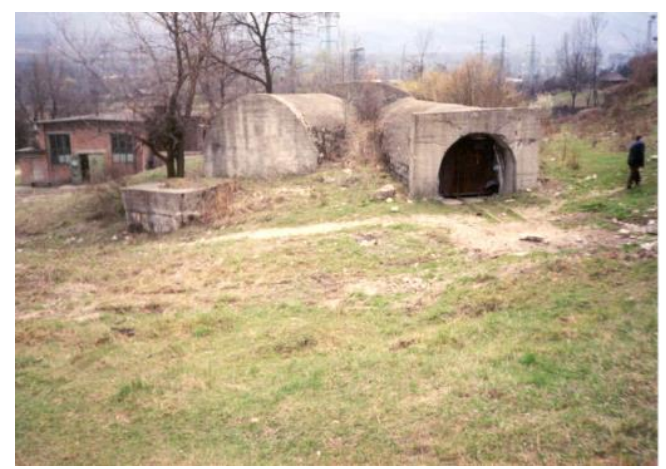

4

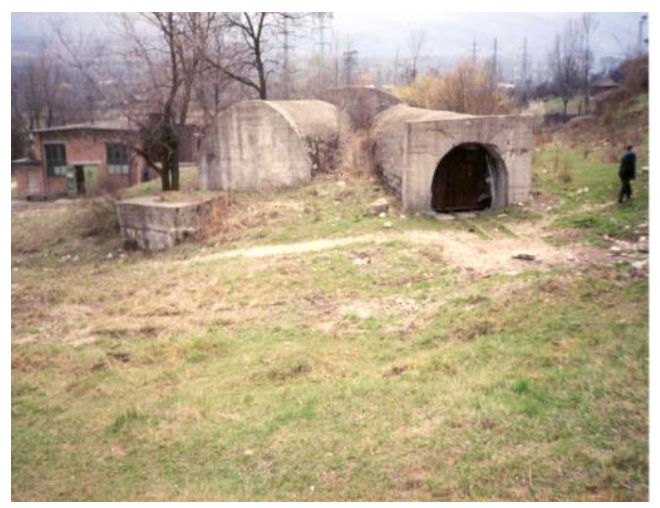

Figure 4. Some constructions from mine yard that is being demolished [11]

1-Raise South fan station; 2- Ventilation ducts precinct Plan 23;

3- Fan station no.1 precinct Plan 23; 4- Fan station precinct Plan 23

Table 3. Compliance program for the greening of the Paroseni mine [12]

\begin{tabular}{|c|c|c|c|}
\hline $\begin{array}{l}\text { No. } \\
\text { crt. }\end{array}$ & $\begin{array}{c}\text { Environmental component/ } \\
\text { Polluting factor }\end{array}$ & Measures & Steps \\
\hline 1 & $\begin{array}{l}\text { SOIL } \\
\text { A. Precinct (Ventilation Raise } \\
\text { South, Ventilation Plan 23) } \\
\text { B. Dump Tericon } \\
\text { level } 630\end{array}$ & $\begin{array}{l}\text { Recovery of occupied lands, } \\
\text { ecological reconstruction } \\
\text { and prevention of } \\
\text { environmental damage } \\
\text { Dump recovery and its } \\
\text { return to the economic } \\
\text { circuit }\end{array}$ & $\begin{array}{l}\text { Precinct arrangement. } \\
\text { - decommissioning/demolition of objects intended for } \\
\text { this purpose; } \\
\text { - land clearing of reusable materials and dumping of non- } \\
\text { biodegradable materials; } \\
\text { - leveling the lands with a slope imposed by the land } \\
\text { configuration; } \\
\text { - biological recultivation of land with adequate vegetation } \\
\text { Dump arrangement } \\
\text { - cleaning the dump of non-biodegradable materials; } \\
\text { - leveling the dump with an imposed slope; } \\
\text { - weeding the dump }\end{array}$ \\
\hline 2 & $\begin{array}{r}\begin{array}{l}\text { WATERS } \\
\text { Rainwater }\end{array} \\
\end{array}$ & $\begin{array}{l}\text { Directing rainwater to guard } \\
\text { channels }\end{array}$ & Periodic clearing of existing guard channels \\
\hline 3 & \begin{tabular}{|l} 
AIR \\
Dust emissions \\
Noise
\end{tabular} & $\begin{array}{l}\text { Reduction of air pollution } \\
\text { Reduction of noise pollution }\end{array}$ & $\begin{array}{l}\text { Application of solutions to limit dust emissions in the } \\
\text { conditions of exceeding the allowed norms: } \\
\quad \text { - demolition; } \\
-\quad \text { for transport. } \\
\text { Application of soundproofing solutions for machines in } \\
\text { function of generating noise above the allowed norms. }\end{array}$ \\
\hline 4 & $\begin{array}{l}\text { Monitoring all environmental } \\
\text { components: soil, water, air }\end{array}$ & $\begin{array}{l}\text {-land tracking and its analysis; } \\
\text {-monitoring water quality } \\
\text { (surface and groundwater); } \\
\text {-monitoring air quality; } \\
\text {-monitoring the development } \\
\text { of sowings; } \\
\text {-following the stability of the } \\
\text { lands by topographic } \\
\text { measurements made by } \\
\text { tracking alignments; } \\
\text {-periodic clearing of existing } \\
\text { guard channels. }\end{array}$ & \\
\hline
\end{tabular}




\subsubsection{Aninoasa mine [12]}

The decision to close the mine was taken because the operation became economically unprofitable, making in 2001 expenses of over 4000 lei per 1000 lei for goods production. Also, due to the non-completion of the opening works due to the limited funding funds and the delay of the preparation works, they led to the impossibility of maintaining the front line. As a result, the exploitable reserve is depleted to the basic horizon. XII (quota + 50).

When drawing up the cessation plan for the Aninoasa mine, the progressive cessation of the mine exploitation activity was taken into account as the prepared reserves were exhausted.

The coal seams, with an east-west direction, have large slopes. The deposit is strongly tectonized, in the northern flank the faults being intercepted by mining works. The coal seams encountered, 2-19, have different thicknesses and areas of spread. The seams 3, 5, 7, 13, 15, 18 are of economic importance. The energy coal exploited in this perimeter is superior in quality to the other perimeters in the basin (lower calorific value of $5,500 \mathrm{kcal} / \mathrm{kg}$ ).

In order to protect the deposit, siltation works were carried out (in the amount of $5,150 \mathrm{~m}^{3}$ ), and the mining works for access to the abatements were dammed with isolation dams to prevent endogenous fires. Also, the networks of mining works related to the coal mining were isolated, with dikes built with prefabricated blocks. These insulating mining constructions were executed in accordance with the "Technical Prescriptions" (PT C 33) at NSPM - ed. 1997.

The closure of the mining works related to the surface (4 shafts, 2 raises) respectively Shaft 1 Piscu, Main North, Main South and Auxiliary and the ventilation raises Parc and Piscu was done by backfilling and construction on their mouths of concrete slabs dimensioned to withstand a load of $32 \mathrm{kN} / \mathrm{m}^{2}$. The horizontal mining works with a cover of less than $50 \mathrm{~m}$ were also closed by backfilling, and their mouths with concrete dikes. On surface no observed changes in the terrain caused by underground exploitation.

\subsubsection{Dâlja mine [12]}

The extractive activity at the Dâlja mine was stopped in 1999, and the mine came into conservation in 2004. In 2005, the works of closing and greening the area began. According to official data, 11 billion lei were allocated and spent for the underground part in order to close the galleries, while for the surface, the amount initially allocated was 82 billion lei, but the organized tender in this regard was won by S.C. IMI. S.A. Baia Mare, for 56 billion lei. Instead of the mining subunit, grass was planted and only two other buildings bear witness to the fact that there was once a coal mine.

\subsubsection{Petrila mine [12]}

The decision to draw up the Activity Cessation Plan of the Petrila mine activity was taken in accordance with article 37 of the Mining Law no. 61/1998 on the basis of the cumulative and partial meeting of the criteria:

a) depletion of reserves in some areas;

b) the continuation of the operation has become impossible due to endogenous fires - whose effects cannot be removed by technical interventions in economic conditions, in other areas.

In order to protect the deposit, the mining works for access to the abatements were dammed with doublerow isolation dams of vaults (6 pcs. in GDM-10.0 profile) to prevent endogenous fires.

During the period of accomplishment of the works and operations of conservation of the mine, the constructions and installations that serve the transport of personnel and materials, aeration, water evacuation, were kept in operation.

Also, during the period of the mine conservation works and operations, the electricity and thermal energy supply installations, the underground gas emission measurement installations, the pumping stations for water evacuation, as well as the operation were maintained. and drinking and industrial water supply installations.

After the completion of the conservation works, the actual closure of the Petrila mine took place.

In order to protect the deposit and the surface, the phased closure of the underground mining works in retreat was carried out, from the limit of the extraction field to the aeration circuits under the general depression of the mine, respectively to the surface connections by leaving them in the state find out the insulation with built dams, built according to the technical prescriptions in force or concreted (for retaining the embankment in the ramps of the wells and suites) whose constructive characteristics are determined by the calculation of the pressure resistance of the embankment column. 
The closure of the mining works related to the surface ( 3 shaft, 1 raise) respectively Shaft 3 East, Shaft 1 East, Shaft 2 East and Central Raise was done by filling and construction on their mouth of 10 concrete slabs (PB-5; PB- 4; SB-3,1) dimensioned to withstand a load of $32 \mathrm{kN} / \mathrm{m}^{2}$.

The horizontal mining works with a cover of less than $50 \mathrm{~m}$ were also closed by filling, and their mouths with concrete dikes.

The surface works for the closure of the Petrila mine provided for the decommissioning and demolition of all the existing buildings and constructions in the 4 precincts of the mine: Shaft 1 East Precinct, Shaft 2 East Precinct, Shaft 3 East Precinct and Central Raise Precinct.

The total closure of the Petrila mine will have positive effects on the environment regarding the environmental components: soil, water, air because the sources of pollution in this area (eg. wastewater from the mine) will disappear.

The dumps related to the mine will be grassed, forested and returned to the economic circuit.

Currently, there are changes in land area caused by underground exploitation in the eastern part of the development-exploitation perimeter.

In order to monitor possible deformations of the land surface caused by underground works, topographic measurements must be performed on well-established alignments.

\subsubsection{Lonea mine [12]}

Lonea mine is in the process of closing/preserving.

The closure works of the Lonea mine consist in the execution of the necessary works for ecological reconstruction and prevention of environmental damage.

The execution of ecological reconstruction works will have positive effects on environmental factors, as well as for the protection of human settlements.

Ecological reconstruction works are required due to the current situation of the mine.

The greening works provided in the documentation are the following.

- in the eastern part of the lake (from the former Jieț open pit), at the base of the slope of the dump near the Jiet brook, gabions will be made in order to protect the dump on a length of $400 \mathrm{~m}$;

- anti-erosion fences will be made on a length of $400 \mathrm{~m}$.

For the restoration in the economic circuit of the lands occupied by the Lonea mine, cleaning, sowing and afforestation works will be carried out.

The sowing works will be carried out on an area of $4000 \mathrm{~m}^{2}$.

The afforestation works will be carried out on the slopes of the dump, thus preventing possible landslides. The afforestation will be done on an area of $4000 \mathrm{~m}^{2}$.

- works will be carried out to unclog the existing collecting channels on a length of $600 \mathrm{~m}$.

- an extension of the existing collector channel will be executed on a length of 50m, until the connection with the existing manhole.

- a stone support of the slope (on both sides) of the access road to Jieț will be executed, on a length of $300 \mathrm{~m}$ on both sides of the road.

The closure of the objectives at the surface of the Lonea mine will have positive effects on the environment regarding the environmental components, by ceasing the industrial activities from these objectives.

In order to collect the rainwater that drains on the slopes of the road, the existing collecting canals will be unclogged and a new one will be built on a length of $50 \mathrm{~m}$, in order to take over the rainwater from the area.

For a good stability of the dumps, afforestation works will be carried out, thus preventing possible landslides.

The compliance program is shown in table 4 .

Recently, specialists have found the aggravation of the phenomenon of subsidence-surface deformations, caused by the underground exploitation of coal.

\section{Analysis of the closure of the mines in Valea Jiului}

A complete analysis, at this date, of the state of the mining perimeters in the Valea Jiului that have closed or are in the process of conservation-closure is difficult to perform for several reasons [6]:

- relatively short duration of mine closure (max. 20 years). Experience in Romania and internationally has shown that the deformation of the surface, resulting from the underground exploitation of coal seams usually occurs after 35-40 years from the cessation of exploitation; 
Table 4. Compliance program for the greening of the Lonea mine site [12]

\begin{tabular}{|c|c|c|c|}
\hline \begin{tabular}{l|} 
No. \\
crt.
\end{tabular} & $\begin{array}{c}\text { Environmental component/ } \\
\text { Polluting factor }\end{array}$ & Measures & Steps \\
\hline$\overline{1}$ & $\begin{array}{l}\text { SOIL } \\
\text { Precincts and dumps }\end{array}$ & $\begin{array}{l}\text { Ecological } \\
\text { reconstruction and } \\
\text { prevention of } \\
\text { environmental } \\
\text { damage }\end{array}$ & $\begin{array}{ll}\text { Ecological reconstruction works consist of: } \\
\text { - } & \text { land clearing, } S=0.4 \mathrm{ha} ; \\
\text { - } & \text { land leveling; } \\
\text { - } & \text { dump grass, } S=0.4 \mathrm{ha} ; \\
\text { - } & \text { dump afforestation, } S=0.4 \mathrm{ha} ; \\
\text { - } & \text { execution of anti-erosion fences }-400 \mathrm{~m} .\end{array}$ \\
\hline 2 & $\begin{array}{l}\text { AIR } \\
\text { Dust emissions }\end{array}$ & $\begin{array}{l}\text { Reducing air } \\
\text { pollution }\end{array}$ & $\begin{array}{l}\text { Application of soundproofing solutions for machines, } \\
\text { depending on the noise generators above the allowed norms. }\end{array}$ \\
\hline 3 & WATER & $\begin{array}{l}\text { Rainwater } \\
\text { collection }\end{array}$ & $\begin{array}{l}\text { For the collection of rainwater, a collecting channel with a } \\
\text { length of } 50 \mathrm{~m} \text { will be executed; } \\
\text { Clogging of existing channels. }\end{array}$ \\
\hline 4 & $\begin{array}{l}\text { Monitoring all environmental } \\
\text { components: soil, water, air }\end{array}$ & & $\begin{array}{l}\text { - monitoring the technical condition of collecting channels; } \\
\text { - periodic monitoring of the quality of the collected waters; } \\
\text { - soil quality monitoring: fertility, chemical composition, } \\
\text { physical structure. }\end{array}$ \\
\hline
\end{tabular}

- the information provided by the Geo-Topo services from me is not always edifying, the topographic measurements in the field are often made only when dangerous geomechanical phenomena occur;

- there is no database containing the situation of the exploitation of coal seams in all mining perimeters;

- there is no systematic monitoring of the land surface from the perimeters exploited by topographic measurements, laser scanners, photogrammetry, e.a.

- a private person, be it a doctoral student, obtains with difficulty or not at all information related to the state of closed mining perimeters, personal observations in the field can often be expressed quantitatively in order to draw accurate scientific conclusions.

However, an analysis of the underground structure of the mines in Valea Jiului may anticipate the occurrence of post-closure phenomena caused by a number of synergistic factors [12]:

a) the not very great depth of location of the underground excavations (below 242-275m);

b) the movement of large volumes of rocks from the roof, following the exploitation with a mined coal bank, a method of exploitation almost generalized, at present, at the mines in the Valea Jiului (over 10-35m);

c) the movement of rock masses according to the fault planes (reactivation of faults), determined by the approach of the panels in operation;

d) concentration of stresses on the corners of the pillars.

e) uncontrolled surface releases of methane from closed mines can be sources of air pollution in the area;

f) uncollected mine waters are a source of pollution of the surface and / or groundwater.

It must be said that in Valea Jiului, wherever the conditions synthesized above are established, baskets/ potholes or other geomechanical phenomena can appear.

In the period 1996-2020, very few controls were carried out by the bodies authorized to verify the manner in which the conservation-closure and greening works of the lands released from constructions were carried out.

Thus, under the control of the Ministry of Environment, Waters and Forests in 2006, [14] to verify the manner in which the Câmpu lui Neag and Petrila Sud Mines were closed, many problems were found in the Mine Closure Report.

After the closure of these mines, in a short period of time, dynamic phenomena appeared on the surface (landslides, surface collapses with crater formation, cracks), which is explained in the Mine Closure Report of the Ministry of Environment and Water Management, National Environmental Guard, General Commissariat.

Following the control carried out in 2006 on closed mining objectives until 2001, it was found that, after the reception at the end of the works, in the perimeters verified by sampling, the process of closing the mines (which includes the phases of design, approval, execution, reception at completion of works, final reception and post-closure monitoring) is inadequate.

Representatives of the Local Public Administrations and of the community did not participate in the realization of the Mining Cessation Projects and the Technical Projects for Closing the mining operations in Valea Jiului. The consultation with the local public administrations was made and is done only when certain surface constructions, lands, sterile dumps, etc. are handed over. City halls have no expertise to study the technical execution project for mine closure and analysis of the influence of the closure method for everything on the surface: buildings, public spaces, infrastructure, pasture, water, etc. [14]. 
If each City Hall had knowledgeable specialists in mining activities (mining engineers, surveying engineers and construction engineers) things would be completely different. The approval of the City Hall for the acceptance of the Technical Project for closing the mine would be based on a special consultation with additional additions necessary to protect surface constructions, delimitation of dangerous perimeters and their monitoring, execution of consolidation works (retaining walls, drilling and injections for stabilization of dangerous areas for landslides, etc.).

There are many examples of mine closures, where, during or after the short monitoring period, dynamic effects appeared that endangered and endangered the households and lands of the inhabitants of Valea Jiului.

These are technical issues that raise questions, including:

- Criteria for establishing the cessation of production activity.

- The period between the last day of production and the completion of the technical closure project is extremely short (1 year) and does not reflect the time required for: recovery of equipment and materials in accordance with the inventory of that time; execution of technical works for the closure of underground works; no backfilling works are carried out on the mine galleries, adjacent to the protection pillars of the populated areas, of the traffic routes, of the watercourses, of other surface objectives.

- The buildings that represent industrial historical monuments are not treated in a separate chapter, an aspect that generated a lot of controversy in the case of the demolition of some buildings inside the former Petrila mine, between the Ministry of Culture and the Ministry of Energy.

- The fact that in any of the 9 (nine) mining premises closed between 1994 and 2016, no museum of coal mining in the Valea Jiului was built, remains a mystery. Who wants to stop hearing about Romanian coal mining?

Now, for the closure of the remaining mining operations in Valea Jiului, there are projects, U.E. funds. and budgetary, but the technical projects must take into account the aspects presented in 2006 by the Ministry of Environment, Waters and Forests. In the future of the Valea Jiului there is a danger of a gradual or sudden sinking, and the occurrence of a medium intensity earthquake can lead to a major disaster in this micro-region, including communities and the environment [14].

The Research Center for Sustainable Urban Regeneration-Valea Jiului (CCRUD-VJ) [14] considers that for the Valea Jiului, in the conditions of closing all mines until 2024, a General Project for Sustainable Urban Regeneration of Valea Jiului Microregion is needed, carried out by University of Petroșani.

$C C R U D-V J$ wants to create together with the City Halls of the Valea Jiului localities, a digital Platform, which through local partnership, to inventory and research the potential of local resources (human capital, natural capital, material capital, investment capital a.o.) and solve the problem lands and buildings of brownfields type (disused industrial areas) from Valea Jiului mining perimeters, by creating a Monitoring and Control Office for Valea Jiului Mining Perimeters, within which will be pursued:

- Natural risk maps for landslides or diving, in the mining perimeters of the Valea Jiului;

- Monitoring the deformation of surface lands and constructions;

- Identification of high risk areas and buildings;

- Realization of the deformation forecast of lands and constructions;

- Restoration of land that has reached stabilization;

- Monitoring the stability of dumps, tailings ponds, roads, buildings, ash depots, etc.

- Monthly newsletter for City Halls, on the situation of mining perimeters and the measures required;

- By verifying the Cessation Project of the mine and the Technical Execution Project for the closure of the mine, CCRUD-VJ., Can bring additional additions and measures, which aim at: avoiding the phenomena of sudden sinking; mine enclosures and roads; dumps; ownership regime.

These Responsible for the supervision of the mining perimeters will be able to carry out a prevention activity within the City Halls and together with the Bureau of Monitoring and Control of the Mining Perimeters from Valea Jiului within CCRUD-VJ will ensure that the realization and direction of the technical projects in accordance with and in safety. From the researches of the specialists from the University of Petroşani it is clear that in the mining perimeters there are and will be sinking of the surfaces, and these areas will have to be delimited, fenced and monitored. Within the activity of these Offices, it will be possible to identify all the citizens' alerts, solutions will be proposed for the affected areas, and the monthly reports will be presented D.G.R.M.

We consider necessary the preventive actions because the sudden closure of the mines in the Valea Jiului took the Local Public Administrations, the Ministry of Economy, the Ministry of Energy, the Ministry of Regional Development and Public Administration, the Ministry of European Funds, the Ministry of Environment, the Ministry of Waters and Forests, the Ministry of Public Finance, The Ministry of Labor and Social Justice and the National Agency for Mineral Resources. Even if we are now talking about a restriction of the public administration staff, the 
Valea Jiului micro-region is a very special area, where it is necessary to supervise the execution of the technical projects for closing the mines. According to the Mining Framework Regulations, the provision of a designated person to keep in touch with the community and the "open doors" program do not ensure peace in the Valea Jiului community. For the Technical Project for the closure of the mine, the designer is obliged to obtain several agreements and approvals, including the Construction Permit, issued by the County Council. It is not necessary to consult or approve the City Hall in the area where the mine is located, which is a serious issue. After the completion of the works, the land areas are handed over by DGRM, to the Local Public Authorities. The fact that, only at the end, the City Halls enter a role, is negatively signaled by the Ministry of Environment, Waters and Forests, since 2006.

A negative and dangerous impact on the environment is represented by quarries and tailings dumps. They were not included in programs and projects for the consolidation of adjacent areas and fencing, and nature entered its role, with landslides and landslides, and people, digging for scrap metal.

Also, the tailings ponds at the Coroieşti Preparation Plant are a "powder keg" for the environment. There is no plan or project to consolidate and secure the dams of these ponds. A natural disaster of red code or an earthquake of medium intensity, can produce an ecological disaster on the Jiu River and even on the Danube.

The Ministry of Environment, Waters and Forests at that time, states in the Mine Closure Report, that in the next period many mining perimeters will be closed, and taking into account the requirements of the European Union Directive no. 2006/21/EEC on the management of extractive waste (the obligation to inventory closed mining areas and their classification according to the danger they pose), in order to improve the process of closing mines and quarries, are necessary [13].

- The global and non-sectoral approach to the environmental issues in the mining perimeters subject to closure and the inclusion in the technical projects for the closure of the activity, of all aspects that have created environmental damage. For example: mine drainage, underground surface water infiltration, funnels and subsurface gaps, mine tailings dumps, surface and underground mining constructions, mining enclosures, access roads etc.

- Establishing in the Cessation Plans (PIA) and in the Technical Projects for Closure of Mines and Environmental Recovery (PT) the possibilities of recovery and use of methane from closed mines, use of mine water as a raw material for hydrogen production (for example), the reprocessing of landfills for the purpose of recovering the carbon fraction and, possibly, for the use of materials recovered in construction, solutions for post-closure redevelopment of closed mines and related dumps, by creating a natural, anthropic and cultural necessary for the development of an ecological tourism in that area etc.

- Establishing from the phase of Cessation Plan (PIA) of the land ownership regime. Solving the handing over of the lands occupied by the mining premises, mining constructions, dumps, collapsing funnels, access roads, etc.

- Creating a unitary legislative framework for the process of closing the mining perimeters. Completing and modernizing the specific legislation, respectively issuing new legislative acts and / or regulations according to the new requirements of the European Union Directive on waste management in the extractive industry. Modification and completion of the Mining Law, the Mine Closing Manual, new closing manuals for salt and uranium, etc.

The seriousness of the issues reported by the Ministry of Environment, Waters and Forests in the 2006 Mine Closure Report did not sensitize the ministries involved to control and manage a situation that may have special consequences in the medium and long term, and proposals to improve the closure process remained the same stage, only as proposals [14].

\section{Conclusions}

Although Valea Jiului is a mining basin of Romania where a coal mine is exploited, which has important balance reserves, currently there are only two viable mines (Livezeni and Vulcan), which can no longer ensure the requirements of the beneficiaries.

Thus, from a first-class mining basin, we are witnessing today, after three decades, the lack of a future energy strategy, to which are added more general causes such as the strategy to reduce carbon dioxide emissions, efficiency lower coal-based energy economy, the development of unconventional less polluting energy sources at a sad end of mining in the Valea Jiului.

The closure of the mines started in 1990 (Iscroni mine) and continues today based on the Closure Plans (PIA) and Technical Projects (PT).

The paper, analyzing how these documents are developed, but also how they were made in the field, concluded that a complete analysis, at this date, of the state of the mining perimeters in Valea Jiului that have closed or are in the process Preservation-closure is difficult to achieve for several reasons presented in the paper. However, an analysis of the underground structure of the mines in the Valea Jiului may anticipate the occurrence of post-closure phenomena caused by a number of factors with synergistic action. 
Although in the period 1996-2020 very few controls were carried out by the bodies authorized to verify the manner of execution of the conservation-closure and greening works of the lands released from constructions, the control of the Ministry of Environment, Waters and Forests from 2006 is noticeable. , to verify the manner in which the Câmpu lui Neag and Petrila Sud Mines were closed, as a result of which many problems were reported in the Mine Closure Report and presented in detail in this article.

The seriousness of the issues raised in this Report did not sensitize the ministries involved to control and manage a situation that may have significant consequences in the medium and long term, and proposals to improve the closure process remained at the same stage, only as proposals.

Finally, it is considered that the proposal made by the Research Center for Sustainable Urban Regeneration-Valea Jiului (C.C.R.U.D.-V.J.) are relevant, achievable and strictly necessary for the sustainable urban regeneration of the Valea Jiului micro-region.

\section{References}

[1] Cozma E., 2006

Techniques and technologies for closing mining operations (in Romanian), Focus Publishing

[2] Davidoiu A., 2017

The role of coal exploitation in Valea Jiului on the sustainable future of the region -(in Romanian), Doctoral thesis, Petroşani University

[3] Fodor D., Georgescu M., 2017

Mining rescue solutions from Valea Jiului, (in Romanian and English), Mining Revue, vol.22, no. 4/2017

[4] Furtună P., 2002

Solutions regarding the closure and conservation of some mines in Valea Jiului basin (in Romanian), - Doctoral thesis, University of Petroșani

[5] Georgescu M., 2020

Mining in the 21st century, (in Romanian and English), Mining Revue no. 4/2020

[6] Marian D.P., Onica, I. et al., 2019

Study on establishing the causes of the phenomenon of discontinuous subsidence in the Lupeni mining perimeter, (in Romanian), Contract no. 1696 APS / 05.12.2018, University of Petroșani

[7] Muzuran C., 2017

Recovery of the technical-productive infrastructure of the mines in liquidation, (in Romanian), Universitas Publishing House, Petroșani

[8] Roman Liliana, 2021

Critical analysis of mine closure methods in Valea Jiului (in Romanian), -Scientific research report no.2. University of Petroșani

[9] Roman Liliana, 2021

Analysis of subsidence phenomena occurring in the closed mining perimeters of Valea Jiului (in Romanian), - Scientific research report no.3. University of Petroșani

[10]***

Mining Law no. 85/2003 (in Romanian)

[11]***

Mine Closure Manual - Order 273/2001 (in Romanian)

$[12] * * *$

Termination Plans (PIA) and Technical Projects (PT) for mines Uricani, Paroșeni, Aninoasa, Petrila, Lonea, SC I.C.P.M SA, Petroșani 2001-2011 (in Romanian)

$[13] * * *$

Post-closure monitoring of underground and surface insulation mining constructions, SC I.C.P.M SA, Petroșani 20012011 (in Romanian)

[14]***, 2019

Closure plan for access to State aid to facilitate the closure of uncompetitive coal mines Prepared in accordance with Council Decision 2010/787 / EU on State aid to facilitate the closure of non-competitive coal mines. (in Romanian). 